\title{
СЕМАНТИЧНИЙ КРИТЕРІЙ ВИЗНАЧЕННЯ КОНТЕКСТІВ ПОЕТОНІМА
}

\author{
ЕЛЛА КРАВЧЕНКО \\ Донецький національний університет імені Василя Стуса, Вінниця - Україна \\ ella.krav4enko@gmail.com; ORCID: 0000-0001-6821-3940
}

\section{SEMANTYCZNE KRYTERIUM OKREŚLANIA KONTEKSTÓW POETONIMU}

\section{ELLA KRAWCZENKO}

Doniecki Uniwersytet Narodowy imienia Wasyla Stusa, Winnica — Ukraina

\begin{abstract}
STRESZCZENIE. Artykuł poświęcony jest wyznaczeniu oraz analizie kontekstów poetonimu, mającym na celu rozpoznanie procesu onimizacji, kategorii onimicznej, a także kontekstów, które „pracują” na semantyzację, aktualizację, intensyfikację oraz etymologię poetycką nazwy własnej tekstu artystycznego. Podane konteksty mogą tworzyć zintegrowaną formę imię-tekst poprzez wykorzystanie sytuacji nazewniczej, wyjaśnienie zgodności nazwy własnej z przedstawionym obiektem, wynik działania gry, stronicowania itp.

Słowa kluczowe: kontekst, poetyka, poetonim, semantyka, tekst.
\end{abstract}

\section{THE SEMANTIC CRITERION FOR DEFINING CONTEXS OF THE POETONYM}

\author{
ELLA KRAVCHENKO \\ Vasyl’ Stus Donetsk National University, Vinnytsia - Ukraine
}

ABSTRACT. The article deals with the identification and analysis of the contexts of the poetonym, which are supposed to identify onymization, as well as the category of the onym. It also studies the contexts which reveal semantization, emphasis and poetic etymology of the poetonyms. The given contexts are capable of creating collective imagery proper name - text by explaining the circumstances of the naming process, revealing the correspondence of the name to the object named, creating game effect, parodying, etc.

Key words: context, poetics, poetonym, semantics, text.

$\mathrm{H}$ аукова розвідка присвячена виявленню та аналізу контекстів поетоніма, спрямованих на розпізнавання онімізації, онімного розряду, а також контекстів, що “працюють” на семантизацію, актуалізацію, інтенсифікацію, поетичну етимологію власного імені художнього тексту. Наведені контексти здатні утворювати сукупну образність $і$ м'я - текст шляхом експлікації ситуації називання, роз'яснення відповідності власного імені зображуваному об'єкту, породженням ефекту гри, пародіювання і т. ін.

Певним внеском у розбудову теорії поетонімології стане класифікація контекстів поетоніма в семантичному аспекті. На сьогодні докладно прокоментовано контекст "оживлення" внутрішньої форми імені ${ }^{1}$, проте поетонім має

\footnotetext{
${ }^{1}$ См.: В. Н. Михайло в, Экспрессивные свойства и функции собственных имён в русской литературе, [в:] Антология поэтонимологической мысли, Донецк 2008, т. 1, с. 32-48; Э. Б. Магазанник, Ономапоэтика, или “Говорящие имена” в литературе, Ташкент 1978; Н. Я. Бияк, Промовисті імена у художньому творі та перекладі, [в:] „Наукові записки. Серія Мовознавство”, Тернопіль 2000, вип. II, с. 28-36.
} 
безліч засобів і прийомів “співпраці" з текстом, спрямованих на розпізнавання: 1) онімізації; 2) онімного класу.

Працюючи на поетонім, контексти “залучають” його до спільного творення образності. Контекст допомагає розпізнати онімізацію - „перехід апелятива чи апелятивного словосполучення через зміну функції у власне ім'я” (переклад автор. - Е. К. $)^{2}$. Такий контекст необхідний і достатній, коли похідна одиниця відтворює форму протослова (семантична онімізація) ${ }^{3}$. Потреба в розпізнаванні онімного статусу виникає при омонімії твірного (загальної назви) і деривата (власного імені). Ідеться про “промовисті" імена, універсальний засіб поетики оніма: Соняшна (Б.-І. Антонич), Дежавю < фр. déjà vu, ЖивітьУ-Злагодi-Ta-Достатку (Ю. Андрухович), Robak 'хробак, черв'як, робак’4, Snug $<$ англ. snug 'приємний', Flute < англ. flute 'флейта', Snout < англ. snout 'рило', Starveling < англ. starveling 'замірок' (В. Шекспір), Scraper < англ. scraper 'скряга' (В. Теккерей), Traitor < traitor 'зрадник' (Б. Шоу) тощо. Імена $з$ прозорою внутрішньою формою, тотожні до апелятивів, мають більшу експресію та виразність, ніж оніми, утворені за участі словотвірних формантів (граматична онімізація). 3. Жаплова відзначає, що прізвище рос. Коробочка більш метафоричне, ніж Коробочкина $a^{5}$. Контекст розпізнавання імені, омонімічного іменника коробочка, є експліцитним, порівн.: А позвольте узнать фамилию вашу. Я так рассеялся ... приехал в ночное время... - Коробочка, коллежская секретарша 6 . Ю. Манн указує на особливу організацію художнього світу М. Гоголя, де важливе місце відведено „граматично не оформленим прізвищам”, зокрема: Земляника, Коробочка, Яичница, Петух, Пробка, Деепричастие та ін. Такі дивні прізвища - „певного зразка неперетворена дійсність: предмет, річ, поняття” (переклад автор. - Е. К.) $)^{7}$. П. Флоренський уважає, що імена недовтілених персонажів М. Гоголя „неминуче напрошуються в загальні”, перетворюючись на ім'я „певної маски - особи, відщепленої від особистості” (переклад автор. - Е. К. $)^{8}$.

Для розпізнавання онімізації може знадобитися зорове сприйняття тексту, коли узуальна загальна назва набуває графічного зображення власного імені. У філософському вірші М. Заболоцького Меркнут знаки Зодиака... види тварин, птахів, риб, комах і рослин позначені великою літерою, інколи в поєднанні з родовим словом, порівн.: Спит животное Собака, / Дремлет птица Воробей; Ловят Муху колдуны; Дремлет рыба Камбала, / Колотушка туктук-тук, / Спит жсивотное Паук, / Спит Корова, Муха спит; Спит растение Картошка...?. Земні “зодіаки” виражають оживлення матерії, а через весь текст „пролягає шлях напруженого вживання індивідуальної свідомості в загадковий світ буття" (переклад автор. - Е. К.) ${ }^{10}$. Названі вище образи Собака, Во-

${ }^{2}$ Н. В. Подоль ская, Словарь русской ономастической терминологии, Москва 1988, с. 91.

${ }^{3}$ Там же, с. 92.

${ }^{4}$ Łucja M. Szewozyk, Funkcja wartościujaca nazewnictwa literackiego (na materiale wybranych dziet Adama Mickiewicza), [w:] Onomastyka literacka, Olsztyn 1993, c. 148.

5 3. П. Жаплов в, Стилистические функиии илён собственных в Мертвых душах Н. В. Гоголя, [в:] „Ученые записки Азербайджанского педагогического института русского языка и литературы. Серия филологическая", Баку 1957, вып. 5, ч. 1, с. 88-126.

${ }^{6}$ М. В. Гоголь, Мертвые души, [в:] Его же, Собр. соч., в 6 томах, Москва 1952, т. 5, с. 52.

${ }^{7}$ Ю.В.М анн, Поэтика Гоголя, Москва 1978, с. 120-121.

${ }^{8}$ П. Фл о р ен с к и й, Имена: Сочинения, Москва, Харьков 1998, с. 291.

${ }^{9}$ Н. А. Заболоцкий, Избр. соч., Москва 1991, с. 51.

${ }^{10} \Gamma$. Н. Фил иппо в, Философско-эстетические искания Н. Заболоикого, [в:] Его же, Русская советская философская поэзия: Человек и природа, Ленинград 1984, с. 125-171 
робей, Камбала, Корова, Муха, Паук, Картошка, утворені засобом онімізації, відображають народження первозданного, недоназваного світу, де все тільки отримує імена.

У відновленому часопросторі Рекреацій Ю. Андруховича (назва роману походить від лат. recreation - 'відновлення') безліч дійових осіб не удостоєні імен, залишаючись перебиранцями в масках $i$ з розмальованими фізіями, які беруть участь у карнавальній процесії Свята Воскресаючого Духу. Г. Лукаш зазначає, що тканину тексту вибудовує онімна лексика, що „поєднує різні часові виміри: минуле - сучасне - майбутне, створюючи ілюзію ймовірного. [...] прийом травестії проектується на сучасні образи, захоплюючи "дорогою" образи попередніх часів, змішуючи реальні та вигадані постаті”"1. Ю. Андрухович переосмислює тексти I. Котляревського і Дж. Джойса відповідно до твердження У. Еко: „Постмодернізм - це відповідь модернізму: якщо вже минуле неможливо знищити, бо його знищення веде до німоти, його слід переосмислити: іронічно, без наївності [...]" (переклад автор. - Е. К.) ${ }^{12}$. Якщо в "суміші" поетонімів Рекреаиій поєднано "реальне" (Ломоносов, Степан Бандера, Богдан-Ггор Антонич) та вигадане (Чортопіль, Задорожній), минуле (Гендель, Глюк, Рільке) й сучасне (Віталій Коротич, Лех Валенса), то перевдягнені dramatis personae карнавальної процесії, позбавлені імен, характеризуються трагедійно-комічними ознаками 'позачасовості' та 'позапросторовості', порівн.: То були Ангели Божі, Цигани, Маври, Козаки, Ведмеді, Спудеї, Чорти, Відьми, Русалки, Пророки, Отиі Василіани в чорному, Жиди, Пігмеї, Повї̈, Улани, Легіонери, Пастушки, Ягнята, Каліки, Божевільні, Прокажені, Паралітики на Роздорожжу, Вбивиі, Розбишаки, Турки, Індуси, Січові Стрільиі, Волочюги, Кобзарі, Металісти, Самураї, Дармограї, Сердюки, Олійники, Мамелюки, Яничари, Манкурти, Ветерани, Афганиі, Багатодітні Сім'ї, Сарачини, Євреї, Негри, Патриції в тогах, Хвойди, Писарі, Брехуни з висолопленими язиками, Дебіли, Козаки-Запорожиі, Піхота, Музики, Магометани, Маланки, Маланці, Діптянки, Блуднищі, Гуцули, Трояниі, Сармати, Етруски, Гіппі, Сліпиі, Трембітарі, Фіндюрки, Святі з картонними німбами, Гетьмани, Ченці, Панки, Клочари, Цьохлі, Трубадури, Різники, Юристи, Хапуги, Пияки, Лікарі, Ледарі, Араби, Кацапи, Опришки, Отиі Домінікани в білому, Шльондри, Герої, Пиворізи, Мочиморди, Салоїди, Голодраниі, Дуболоми, Сажотруси, Козолупи, Недоріки, Менестрелі, Проститутки - а всіх інших перелічити просто неможливо, бо були там ще Горили, Генерали, Гавіали, Павіани, Павликіани, Данайці, Нанайиі, Німфи, Нівхи, Ассирійці, Арнаути, Торбохвати, Лірники, Сирники, Шинкарі, Македониі, Броварі, Анахорети, Пупорізки, Українці, Лесбіяни, Гноми, Мавки, Мавпи, Лилики, Чорні Коти, Грудні Жаби, Алхіміки, Шльохи, Профури, Татари, Бубабісти ... ${ }^{13}$. Умовність прихованих під маскою осіб, плюральна форма, призначена актуалізувати співвіднесеність “личини” з кількома об' єктами, декларують узагальненість того чи того іменування. Проте відтворення форми апелятива і використання великої літери засвідчують похідний статус "недовтілених" імен (квазіонімів), тому наведені номінації тлумачимо як проміжні одиниці, що “завмерли” на шляху до перевтілення в оніми. Карнавалізація, одягання масок і видавання себе за когось іншого як відмова від індивідуального формують змістовно-концептуальну інформацію твору, герої якого затавровані риса-

${ }^{11}$ Г. П. Лукаш, Травестія I. Котляревського та карнавальність Ю. Андруховича, [в:] „Записки з ономастики” 1999, № 2, с. 36.

12 У. Эко, Заметки на полях Имени Розы, СПб. 2005, с. 461.

${ }^{13}$ Ю. Андрухов ич, Рекреаціï, Київ 1997, с. 68. 
ми 'уподібнення', 'типовість', 'недоособистість', 'неповноцінність'. На думку Г. Лукаш, письменник „хотів показати наше життя з його диявольським павутинням, крізь яке пробивається Боже світло" ${ }^{14}$. Ідея рятування в собі особистості полягає в набутті Імені (суб'єктності) через зняття маски.

Перехід загальна назва $\rightarrow$ власне ім'я може стати приводом для каламбурної омонімії (із використанням повних омонімів, омофонів, омографів, оказіональної омонімії та омоформ). Циркулюючи на осі апелятив - онім, студебеккер / Студебеккер зіштовхує різнорідні характеристики в ігровому контексті, загрунтованому на тотожності фіналій назви автомобіля і традиційного єврейського прізвища на -ер: <..> но ведь в пробеге нет никаких “лорен-дитрихов”! Я читал в газете, что идут два “паккарда", два “фиата" и один “студебеккер”.

- Идите к чёртовой матери со своим “студебеккером”! - заорал Остап. — Кто такой Студебеккер? Это ваш родственник Студебеккер? Папа ваш Студебеккер? < ...> Русским языком ему говорят, что “студебеккер” в последний момент заменён "лорен-дитрихом", а он морочит голову! "Студебеккер”! ... Убивать надо таких знатоков! "Студебеккер” ему подавай!' Комічний ефект досягається “хитанням" сем “неістота' (студебеккер замінено на лорен-дитрих) — 'істота' (кто, родственник, папа), що виражені морфологічно, синтаксично й графічно ${ }^{16}$. Контекст, що демонструє перехід апелятив $\rightarrow$ онім $\rightarrow$ апелятив, є необхідним і достатнім, щоб засвідчити онімізацію та оцінити вартість гри. Отже, контекстом розпізнавання онімізаиії називаємо необхідний і достатній контекст установлення похідності власного імені, яку спричиняє омонімія твірного слова (загальної назви) і деривата (оніма).

Трансонімізація, що інтенсивно протікає в мові, визначає потребу в контексті розпізнавання онімного класу. І. Турута вважає, що оказіональні ергоніми характеризуються подвійною мотивацією, оскільки вступають в омонімічні відношення 3 реальними онімами або вигаданими, тобто поетонімами ${ }^{17}$. Омонімія імен в узусі може ускладнити уналежнення поетоніма до відповідного розряду. Іноді для правильного визначення онімного класу доводиться залучати канонічний текст і рукописи. Коментуючи повернення Онегина і Ленского додому після першого відвідування Онегиним родини Лариных (Они дорогой самой краткой / Домой летят во весь опор. / < ..> / Однако в поле уж темно; / Скорей! Пошёл, пошёл, Андрюшка! / Какие глупые места!), М. Бродський пише: „Ларіна називала кріпачку Акулькою (...); Онєгін кричить: Андрійко; у варіанті XXXVII строфи III глави хлопчика, який подавав вершки, названо Тришкою" (переклад автор. - Е. К.) ${ }^{18}$. В. Калінкін помічає неправильне "прочитання" імені і доводить, що Андрюшка - це зоопоетонім, кличка коня. Можливо, так називали донського жеребця, порівн.: Сначала все к нему езжали; / Но так как с заднего крыльиа / Обыкновенно подавали / Ему донского жеребиа... „На підтвердження того, що Андрюшка позначає коня, — як наголо-

${ }^{14}$ Г. П. Лукаш, Травестія І. Котляревського та карнавальність Ю. Андруховича..., с. 39.

${ }^{15}$ И. Ильф, Е. Петров, Золотой телёнок, [в:] Их же, Двенадиать стульев. Золотой телёнок. Романы, Одесса 1990, с. 356.

${ }^{16}$ См.: С. Е. Дворянчиков а, Поэтика онима в контексте комических жанров и смеховой культуры, Донецк 2014, с. 184.

${ }^{17}$ И. И. Турута, Как корабль назовёшь (заметки о приёмах языковой игры в современной эргонимии), [в:] Лексико-грамматические инновации в современных славянских языках, VII Международная научная конференция 2-4 апреля 2015 г., Днепропетровск, ДНУ имени Олеся Гончара, Дніпропетровськ 2015, с. 182.

${ }^{18}$ Н. Л. Бродский, Евгений Онегин. Роман А. С. Пушкина, пособие для учителей средней школы, Москва 1950, с. 165. 
шує В. Калінкін, - свідчать такі факти: у чернетці попередня, третя строфа закінчувалася так: Сбежались девки из сеней / Смотреть на нового соседа, / А на дворе толпа людей / Критиковала их коней” (переклад автор. - Е. К.) ${ }^{19}$. Зауважуючи, що Онегин і Ленский приїхали до Лариных верхи, науковець пояснює помилку, припущену М. Бродським, ,збігом форм антропоніма та зооніма" (переклад автор. - Е. К. $)^{20}$, тобто омонімією власних імен у мові - головною причиною сплутування об'єктів. Отже, контекстом розпізнавання онімного класу слід уважати необхідний і достатній контекст упізнавання розряду, що зумовлений омонімією й пов’ язаний із процесом трансонімізації.

Змістові “прикмети” поетоніма висвітлюють контексти: 1) семантизації імені його носієм / оповідачем / персонажем; 2) актуалізації та інтенсифікаиії внутрішньої форми імені; 3) поетичної етимологї.

Зазвичай семантизація виявляє домінантні та / або експресивно-оцінні компоненти значення: А один мичман, и даже хороший мичман, был по фамилии просто Дырка. И капитан, бывало: „, Эй тыл, Дырка, поди сюда!” И, бывало, над ним всегда пошутишь. „Эх тыл, дырка эдакой!” — говоришь, бывало, ему ${ }^{21}$; Обрали класну дівку в сексуальному прикиді, щзо так здетонувало з ії козацьким прізвищем Крук, аж у дворі [...] ї̈ пернатий однофамілець каркнув "Nevermore!"”2; Ада Цитрина: [...] ми увірвалися в край, де не стало снігу, де були зелені трави, цүе така земля, ,wo die Zitronen bluhn” (а ти, Цитрино, квітла в цімм краю?) $)^{23}$.

Ідею імені-образу втілюють контексти, що експлікують ситуацію називання: „Ma petite fleur!” — Annette said softly. — “Fleur,” repeated Soames „Fleur! we'll call her that”24 і контексти, що роз'яснюють відповідність імені (прізвиська, псевдоніма тощо) зображуваному об'єкту: [Собакевич] [...] nоказался весьма похожим на средней величины медведя. Для довершения сходства фрак на нём был совершенно медвежьего цвета, [...] ступнями ступал он вкривь и вкось и наступал беспрестанно на чужие ноги. [...] медведь! совершенный медведь! Нужно же такое странное сближение: его даже звали Михаилом Семёновичем 25 ; Лазар ненавидів тюремного смотрителя, якому тюрма дала прізвище Морда. За все: за грубу пику, на якій не хотіло рости волосся, за маленькі жорстокі очі, щзо завжди дивились кудись поза людину, хоч все помічали, за його вдачу мучителя ${ }^{26}$. Останній тип контексту надає персонажу „тих властивостей, які, за сформованим у суспільній свідомості уявленням, приховані в імені” (переклад автор. - Е. К.) $)^{27}$. До нього прилягає контекст, що прояснює рефлексію автора / оповідача / персонажа щодо імені (його звучання, асоціативних зв'язків, варіантності, сполучуваності, традиції вживання тощо): Лев Глево... Лев Глебович? Ну и имя у вас, батенька, язык вывихнуть можно < .. > Лев и Глеб - сложное, редкое соединение. Оно от вас требует сухости,

\footnotetext{
${ }^{19}$ В. М. Калин кин, Поэтика онима, Донецк 1999, с. 155.

${ }^{20}$ Там же, с. 155.

${ }^{21}$ Н. В. Гоголь, Женитьба, [в:] Его же, Собр. соч., в 6 томах, Москва 1952, т. 4, с. 124.

22 Л. Ко с тен ко, Записки українського самашедшего, Київ 2011, с. 61.

${ }^{23}$ Ю. Андрухо в ич, Перверзія, Львів 2004, с. 30.

${ }^{24}$ J. Galsw orthy, The Forsyte Saga, [in:] Electronic resourse: http://www.readcentral.com/ book/John-Galsworthy/Read-The-Forsyte-Saga-Volume-I-Online (12.10.2017).

${ }^{25}$ М. В. Гоголь, Мёртвые души..., с. 97-98.

${ }^{26}$ М. М. Коцюби н сь ки й, Persona Grata, [в:] Його ж, Твори, Київ 1988, т. 2, с. 13.

${ }^{27}$ В. М. Калинкин, Поэтика онима..., с. 113.
} 
твёрдости, оригинальности ${ }^{28} ;$ Я знав дівчину. Мала дзвінке ймення: Соня ${ }^{29}$; Пропливаючи під мостом Скальці, Респондент наголосив, що в його школі вчився хлопчик на прізвище Скальський It could not be that if I had invented it myself. I head it a concert of ancient music when I was a child; and I have treasured it ever since ${ }^{31}$; Man antwortete ihm, indem man ihm seinen Namen oder eine Koseform seines Namens mehrfach entgegenrief, und Aschenbach horchte mit einer gewissen Neugier darauf, ohne Genaueres erfassen zu können, als zwei melodische Silben wie 'Adgio' oder öfter noch 'Adgiu' mit rufend gedehntem u-Laut am Ende s2 $^{2}$ і т. д.

У Bend Sinister (В. Набоков) головний герой Aдам Круг має кілька гротескних двійників (Круг, Гурк), але ключовий прийом поетики полягає в актуалізації та інтенсифікації внутрішньої форми “промовистого" прізвища. Обмежимося інтенсифікувальними контекстами, де зв'язок імені з омонімічним апелятивом виражений чітко, порівн.: Круг с бакалейщиком шли через мост; по крайности Круг шёл; его маленький спутник выплёскивал исступлённую радость, бегая вокруг Круга, он бежал, расширяя круги [... ${ }^{33}$; Бакалейщик завершил круговращение спиралью, вернувшей его в орбиту Круга; [...] подумал Круг, круг в Круге, один Круг в другом ${ }^{34}$; Круг шагал впереди, в круге света $[\ldots]^{35}$.

Відродження образності імені за допомогою реетимологізації (термін О. Трубачова ${ }^{36}$ ), або поетичної семантизації (етимології), набуває особливої значущості у віршованому тексті. Повторення еквівалентних фонем у словах, що римуються з поетонімом, уважають поширеним прийомом поетичного тексту. Порівн.: Слова шовкові хитають п'яно, /[...]/ Душної ночі солодкий Пане ${ }^{37} ;$ О жорстоке століття, закроєне з воєн $і$ боєнь! / Не встигаєм забути усе, щзо до нас відбуло, / Як на голови нам пада з неба який-небудь “Боӥнг”з8; По яких мені храмах хрипнуть / До кривавих потів на лобі: / Вбережи тебе Боже, Прип'ять, / Вбережи тебе Бог, Чорнобиль?...9; Oranges and lemons, say the bells of St. Clement's, / You owe me three farthings, say the bells of St. Martin 's ${ }^{40}$.

Контекст може бути “налаштований” на сукупний вплив імені на читача. Авторефлексія щодо імені Татьяна (О. Пушкін) стосується милозвучності, простонародності, відсутності літературної традиції вживання, протиставлення свого імені чужим, західноєвропейським ${ }^{41}$ : Её сестра звалась Татьяна... / Впервые именем таким / Страниџы нежные романа / Мы своевольно освятим.

${ }^{28}$ В. Н Н бо ко в, Машенька, [в:] Его же, Собр. соч., в 4 томах, Москва 1990, т. 1, с. 35.

${ }_{29}^{29}$ Б.-І. Антонич, Зелена Свангелія: Поезія. Драматургія, проза, статті, Київ 2009, c. 332.

${ }^{30} Ю$. Андрухович, Перверзія..., с. 46.

31 G. B. Shaw, The Apple Cart, [in:] Electronic resourse: http://gutenberg.net.au/ ebooks03/0300431h.html (12.10.2017).

${ }^{32}$ T. Mann, Der Tod in Veneding, [in:] Electronic resourse: http://www.general-ebooks.com/ $\mathrm{read} / 351816(25.11 .2017)$.

${ }^{33}$ В. Н Н б о ко в, Bend Sinister, СПб. 1993, с. 315.

${ }^{34}$ Там же, с. 332.

${ }^{35}$ Там же, с. 455.

${ }^{36}$ О. Н. Трубачёв, Этимологические исследования и лексическая семантика, [в:] Его же, Принципы и методы семантических исследований, Москва 1976, с. 147-179.

${ }^{37}$ М. Матіо с, Жіночий аркан у саду нетерпіння, Львів 2011, с. 261.

${ }^{38}$ О. 3 а бужко, Друга спроба: Вибране, Київ 2005, с. 57.

${ }^{39}$ Там само, с. 61.

${ }^{40}$ G. Orwe11, 1984, [in:] Electronic resourse: http://orwell.ru/library/ novels/1984/ (12.01.2018).

${ }^{41}$ Я. И. Гин, Из комментариев к Евгению Онегину: Агафон, [в:] „Временник Пушкинской комиссии", СПб. 1993, вып. 25, с. 138. 
/ И что ж? оно приятно, звучно; / Но с ним, я знаю, неразлучно / Воспоминанье старинь / Иль девичьей!"2. Г. Рахімкулова наводить приклад “штучноі” омонімії: Max Lux. Что это у тебя, сказочный огородник? Мак-с. А то? Лук-с, ваша светлость ${ }^{43}$. Двомовна омонімія $\epsilon$ основою поетичної етимології назви перевозчичьей фирмыл, де виникає ,зв'язок між технікою потоку свідомості і штучно створеною омонімією" (переклад автор. - Е. К. $)^{44}$.

На поетику прізвища Яичница (М. Гоголь), мотивованого тотожним апелятивом, “працюють” три узгоджених контексти, у яких виникає та посилюється комічна образність. В. Михайлов трактує прізвище як онімний каламбур, загрунтований на оживленні етимологічного значення ${ }^{45}$. Ю. Тинянов називає головний гоголівський прийом, який використовується “в життєписі людей”, прийомом маски, а прізвища на зразок Земляника й Яичница вважає складнішим розвитком прийому внаслідок „незбіжної за родом словесної маски, що створює набагато більший комічний ефект" (переклад автор. - Е. К.) ${ }^{46}$. Вплив контексту на поетонім починається з роздумів Агафьи Тихоновньл, яка нарікає на “дискомфорт" прізвища потенційного нареченого. "Примірка" прізвища приводить до розчарування: [Агафья Тихоновна]. А фамилия как? [Фёкла]. А фамилия Иван Павлович Яичница. [Агафья Тихоновна]. Это такая фамилия? [Фёкла]. Фамилия. [Агафья Тихоновна]. Ах Боже мой, какая фамилия! Послушай, Феклуша, как же это, если я выйду за него замуж и вдруг буду называться Агафья Тихоновна Яичница? Бог знает что такое! ${ }^{47}$. Наступний контекст актуалізує внутрішню форму імені, посилюючи комізм "зверненням в апелятив": [Жевакин]. [...] Позвольте с своей стороны тоже спросить: с кем-с имею счастье изъясняться? [Иван Павлович]. В должности экзекутора, Иван Павлович Яичница. [Жевакин (недосльишав)]. Да, я тоже перекусил. Дороги-то, знаю, впереди будет довольно, а время холодновато: селёдочку съел с хлебием. [Иван Павлович]. Нет, кажется, вы не так поняли: это фамилия моя - Яичница. [Жевакин (кланяясь)]. Ах, извините! я немножко туговат на ухо. Я, право, думал, что вы изволили сказать, что покушали яичницу48. Цей контекст концентрується на фонетичному обігруванні: [Иван Павлович]. Да что делать? я хотел было уже просить генерала, чтобы позволил называться мне Яичницын, да свои отговорили: говорят, будет похоже на “собачий сын” 49. Причина, через яку персонаж відмовляється змінити прізвище, доповнивши “спадкове” типовим формантом -ин /-ын, полягає у співзвучності (хоч і віддаленій), порівн.: Яичнииа - собачий сын. В. Калінкін кваліфікує цей прийом як уявну омофонію50, а Ю. Манн співвідносить неможливість перетворення прізвища з “масковістю” персонажів М. Гоголя ${ }^{51}$.

${ }^{42}$ А. С. Пушкин, Евгений Онегин, [в:] Его же, Полн. собр. соч., в 10 томах, Москва 1964, т. 5 , c. 47.

${ }^{43}$ В. Набоко в, Дар, [в:] Его же, указ. источ., т. 3, с. 27.

${ }^{44}$ Г. Ф. Рахимкулов а, Языковая игра в прозе В. Набокова (к проблеме игрового стиля), Ростов-на-Дону 2004, с. 28.

${ }^{45}$ В.Н. Михайл о в, Экспрессивные свойства и функции собственных имён в русской литеpamype..., c. 35 .

${ }^{46}$ Ю. Н. Тынянов, Достоевский и Гоголь (к теории пародии), [в:] Его же, Поэтика. История литературы. Кино, Москва 1977, с. 202-203.

${ }^{47}$ Н.В.Гоголь, Женитьба..., с. 117.

${ }^{48}$ Там же, с. 120.

49 Там же, с. 124.

${ }^{50}$ В. М. Калин кин, Поэтика онима..., с. 317.

${ }^{51}$ Ю. В. Манн, Поэтика Гоголя..., с. 121. 
Омонімія власних імен та загальних назв зумовлює вихід прізвища Яичница за “фізичні” межі твору. Ім’я обігрується в романі I. Ільфа та Є. Петрова, коли Ocman Бендер і Воробьянинов приходять на прем’єру гоголівської Женитьбы в постановці театру Колумба. Очікування класичної інтерпретації руйнує "змішування" канонічного тексту з елементами сучасності, унаслідок сюжет пародійно переосмислено: Кочкарьов з Феклою співають куплети про Чемберлена; оркестр грає попурі з Чіо-чіо-сан і т. д. Метаморфози гоголівського тексту виявляються в “зримому” перетворенні прізвища Яичница в омонімічний апелятив: Женихи были очень смешны - в особенности Яичница. Вместо него выносили большую яичницу на сковороде. [Агафья Тихоновна] вышла замуж за Степана. Оба принялись уписывать яичницу, которую подал им обратившийся в лакея Подколесин ${ }^{52}$. У новому художньому часопросторі гра із "чужим" іменем починається деонімізацією та завершується "поїданням персонажа", перевтіленого в неістоту.

Отже, узвичаєними контекстами поетонімів, що працюють на сукупну образність $і$ 'я - текст, стають контексти розпізнавання онімізації чи онімного класу, а також семантизації, актуалізації, інтенсифікації, поетичної етимології власного імені, що експлікують ситуацію називання, роз'яснюють відповідність власного імені зображуваному об'єкту, прояснюють рефлексію автора / оповідача / персонажа щодо звучання, варіантності, традиції вживання обраної номінації, нарощують смисли, породжують ефект гри, пародіювання i т. ін.

\section{Список використаної літератури}

Андрухович Ю., Перверзія, Львів 2004.

Андрухович Ю., Рекреачії, Київ 1997.

Антонич Б.-І., Зелена Свангелія: Поезія. Драматургія, проза, статті, Київ 2009.

Бияк Н. Я., Промовисті імена у художньому творі та перекладi, [в:] „Наукові записки. Серія Мовознавство", Тернопіль 2000, вип. II, с. 28-36.

Бродский Н. Л., Евгений Онегин. Роман А. С. Пушкина, пособие для учителей средней школы, Москва 1950.

Гин Я. И., Из комментариев к Евгению Онегину: Агафон, [в:] „Временник Пушкинской комиссии", СПб. 1993, вып. 25, с. 138-148.

Гоголь Н. В., Женитьба, [в:] Его же, Собр. соч., в 6 томах, Москва 1952, т. 4.

Гоголь Н. В., Мертвые души, [в:] Его же, Собр. соч., в 6 томах, Москва 1952, т. 5.

Дворянчикова С. Е., Поэтика онима в контексте комических жанров и смеховой культуры, Донецк 2014.

Жаплова 3. П., Стилистические функиии имён собственных в Мертвых дущах Н. В. Гоголя, [в:] „Ученые записки Азербайджанского педагогического института русского языка и литературы. Серия филологическая", Баку 1957, вып. 5, ч. 1, с. 88-126.

Заболоцкий Н. А., Избр. соч., Москва 1991.

Забужко О., Друга спроба: Вибране, Київ 2005.

Ильф И., Петров Е., Двенадцать стульев, [в:] Их же, Двенадиать стульев. Золотой телёнок. Романы, Одесса 1990.

Ильф И., Петров Е., Золотой телёнок, [в:] Их же, Двенадиать стульев. Золотой телёнок. Романы, Одесса 1990.

Калинкин В. М., Поэтика онима, Донецк 1999.

Костенко Л., Записки українського самашедшего, Київ 2011.

${ }^{52}$ И. Ильф, Е. Петров, Двенадиать стульев, [в:] Их же, Двенадияать стульев. Золотой телёнок. Романы, Одесса 1990, с. 220. 
Коцюбинський М. M., Persona Grata, [в:] Його ж, Твори, Київ 1988, т. 2.

Лукаш Г. П., Травестія І. Котляревського та карнавальність Ю. Андруховича, [в:] „Записки з ономастики” 1999, № 2, с. 32-38.

Магазанник Э. Б., Ономапоэтика, или “Говорящие имена” в литературе, Ташкент 1978.

Манн Ю. В., Поэтика Гоголя, Москва 1978, с. 120-121.

Матіос М. М., Жіночий аркан у саду нетерпіння, Львів 2011.

Михайлов В. Н., Экспрессивные свойства и функции собственных имён в русской литературе, [в:] Антология поэтонимологической мысли, Донецк 2008, т. 1, с. 32-48.

Набоков В., Bend Sinister, СПб. 1993.

Набоков В., Дар, [в:] Его же, Собр. соч., в 4 томах, Москва 1990, т. 3.

Набоков В., Машенька, [в:] Его же, Собр. соч., в 4 томах, Москва 1990, т. 1, с. 35.

Подольская Н. В., Словарь русской ономастической терминологии, Москва 1988, с. 91.

Пушкин А. С., Евгений Онегин, [в:] Его же, Полн. собр. соч., в 10 томах, Москва 1964, т. 5.

Рахимкулова Г. Ф., Языковая игра в прозе В. Набокова (к проблеме игрового стиля), Ростов-на-Дону 2004.

Трубачёв О. Н., Этимологические исследования и лексическая семантика, [в:] Его же, Принципы и методы семантических исследований, Москва 1976, с. 147-179.

Турута И. И., Как корабль назовёшь (заметки о приёмах языковой игры в современной эргонимии), [в:] „Лексико-грамматические инновации в современных славянских языках, VII Международная научная конференция 2-4 апреля 2015 г., Днепропетровск, ДНУ имени Олеся Гончара, Дніпропетровськ 2015, с. 180-186.

Тынянов Ю. Н., Достоевский и Гоголь (к теории пародии), [в:] Его же, Поэтика. История литературы. Кино, Москва 1977, с. 202-203.

Филиппов Г. Н., Философско-эстетические искания Н. Заболоикого, [в:] Его же, Русская советская философская поэзия: Человек и природа, Ленинград 1984, с. 125171.

Флоренский П., Имена: Сочинения, Москва, Харьков 1998.

Эко У., Заметки на полях Имени Розы, СПб. 2005.

Galsworthy J., The Forsyte Saga, [in:] Electronic resourse: http://www.readcentral.com/book/ John-Galsworthy/Read-The-Forsyte-Saga-Volume-I-Online (12.10.2017).

Mann T., Der Tod in Veneding, [in:] Electronic resourse: http://www.general-ebooks.com/ $\mathrm{read} / 351816(25.11 .2017)$.

Orwell G., 1984, [in:] Electronic resourse: http://orwell.ru/library/ novels/1984/ (12.01.2018).

ShawG.B., The AppleCart,[in:]Electronic resourse:http://gutenberg.net.au/ebooks03/0300431h. html (12.102017).

Szewozyk Łucja M., Funkcja wartościujaca nazewnictwa literackiego (na materiale wybranych dziet Adama Mickiewicza), [w:] Onomastyka literacka, Olsztyn 1993. s. 146-154.

\section{Spysok vykorystanoi literatury [References]}

Andrukhovych Yu., Perverziia [Perversion], Lviv 2004.

Andrukhovych Yu., Rekreatsii [Recreations], Kyiv 1997.

Antonych B.-I., Zelena Yevanheliia: Poeziia. Dramaturhiia, proza, statti [Green Gospel: Poetry, Drammaturgy, Proze, Articles], Kyiv 2009.

Byiak N. Ya., Promovysti imena u khudozhnomu tvori ta perekladi, [v:] „Naukovi zapysky. Seriia Movoznavstvo", Ternopil 2000, vyp. II, s. 28-36.

Brodskij N. L., Evgenij Onegin. Roman A. S. Pushkina [Eugene Onegin. Novel by A. Pushkin], posobie dlya uchitelej srednej shkoly, Moskva 1950.

Gin Ya. I., Iz kommentariev k Evgeniju Oneginu: Agafon [From Comments on Eugene Onegin: Agafon], [v:] „Vremennik Pushkinskoj komissii”, vyp. 25, SPb. 1993.

Gogol N. V., Zhenitba [Getting Married], [v:] Ego zhe, Sobr. soch., v 6 tomah, t. 4., Moskva 1952. 
Gogol M. V., Mertvye dushi [Dead Souls], [v:] Ego zhe, Sobr. soch., v 6 tomah, t. 5., Moskva 1952.

Dvoryanchikova S. E., Poe 'tika onima v kontekste komicheskih zhanrov i smehovoj kultury [Poetics of Onym Context of Comic Genres and Laughter Culture], Doneczk 2014.

Zhaplova Z. P., Stilisticheskie funkcii imyon sobstvennyh v Mertvyh dushah N. V. Gogolya [Stylistic Functions of Proper Names in Mertvye Dushy by N. V. Gogol], [v:] „Uchenye zapiski Azerbajdzhanskogo pedagogicheskogo instituta russkogo yazyka i literatury. Serija filologicheskaya", Baku 1957, vyp. 5, ch. 1, s. 88-126.

Zabolockij N. A, Izbr. soch. [Selected Works], Moskva 1991.

Zabuzhko O., Druha sproba: Vybrane [The Second Attempt: Selected], Kyiv 2005.

Ilf I., Petrov E., Dvenadczat'stul'ev [Twelve Chairs], [v:] Ih zhe, Dvenadczat'stul'ev. Zolotoj telyonok. Romany, Odessa 1990.

Ilf I., Petrov E., Zolotoj teljonok [Golden Calf], [v:] Ih zhe, Dvenadczat'stul'ev. Zolotoj telyonok. Romany, Odessa 1990.

Kalinkin V. M., Poe `tika onima [Poetics of Onym], Doneczk 1999.

Kostenko L., Zapysky ukrainskoho samashedsheho [The Notes of Ukrainian Insane], Kyiv 2011.

Kotsiubynskyi M. M., Persona Grata, [v:] Yoho zh, Tvory, t. 2., Kyiv 1988.

Lukash H. P., Travestiia I. Kotliarevskoho ta karnavalnist Yu. Andrukhovycha [Travesty of I. Kotliarevskyi and Carnavalism of Yu. Andrukhovych], [v:] „Zapysky z onomastyky”, № 2, 1999.

Magazannik E`. B., Onomapoe `tika, ili "Govorjashhie imena” v literature [Onomapoetics, or "Speaking Names" in Literature], Tashkent 1978.

Mann Yu. V., Poe 'tika Gogolya [Poetics of Gogol], Moskva 1978.

Matios M. M., Zhinochyi arkan u sadu neterpinnia [Voiced Arkan in the Garden of Intranquility], Lviv 2011.

Mihajlov V. N., E kspressivnye ssvojstva i funkcii sobstvennyh imyon v russkoj literature [Expressive Peculiarities and Functions of Proper Names in Russian Literature], [v:] Antologiya poe tonimologicheskoj mysli, Doneczk 2008, t. 1, s. 32-48.

Nabokov V., Bend Sinister, SPb. 1993.

Nabokov V., Dar [Gift], [v:] Ego zhe, Sobr. soch., v 4 tomah, t. 3, Moskva 1990.

Nabokov V., Mashenka [Mashenka], [v:] Ego zhe, Sobr. soch., v 4 tomah, t. 1., Moskva 1990.

Podol'skaya N. V., Slovar'russkoj onomasticheskoj terminologii [Dictionary of Russian Onomastic Terminology], Moskva 1988.

Pushkin A. S., Evgenij Onegin [Eugene Onegin], [v:] Ego zhe, Poln. sobr. soch., v 10 tomah, t. 5, Moskva 1964.

Rahimkulova G. F., Yazykovaya igra v proze V. Nabokova (k probleme igrovogo stilya) [Language Game in V. Nabokov prose (on the Problem of Game Style)], Rostov-na-Donu 2004.

Trubachyov O. N., E`timologicheskie issledovaniya i leksicheskaya semantika [Etymological Researches and Lexical Sermantics], [v:] Ego zhe, Principy i metody semanticheskih issledovanij, Moskva 1976, s. 147-179.

Turuta I. I., Kak korabl' nazovyosh' (zametki o priyomah yazykovoj igry v sovremennoj e'rgonimii) [The Way you Name the Ship (Sketches on Ways of Language Game in Modern Terminilogy)], [v:] Leksiko-grammaticheskie innovacii v sovremennyh slavyanskih yazykah, VII Mezhdunarodnaya nauchnaya konferenciya 2-4 aprelya 2015 g., Dnepropetrovsk, DNU imeni Olesya Gonchara, Dnipropetrovs'k 2015, s. 180-186.

Tynyanov Yu. N., Dostoevskij i Gogol' (k teorii parodii) [Dostoevskiy and Gogol (on the Theory of Parody)], [v:] Ego zhe, Poehtika. Istoriya literatury. Kino, Moskva 1977, s. 202-203.

Filippov G. N., Filosofsko-e 'steticheskie iskaniya N. Zabolotskogo [Philosophical, Esthetic Searches of N. Zabolockyi], [v:] Ego zhe, Russkaya sovetskaya filosofskaya poe ziya: Chelovek i priroda, Leningrad 1984, s. 125-171.

Florenskij P., Imena: Sochinenija [Names: Works], Moskva-Kharkov 1998. 
E`ko U., Zametki na polyah Imeni Rozy [Notes in Margins of Name Rose], SPb. 2005.

Galsworthy J., The Forsyte Saga, [in:] Electronic resourse: http:/www.readcentral.com/book/ John-Galsworthy/Read-The-Forsyte-Saga-Volume-I-Online (12.10.2017).

Mann T., Der Tod in Veneding, [in:] Electronic resourse: http://www.general-ebooks.com/ $\mathrm{read} / 351816(25.11 .2017)$.

Orwell G., 1984, [in:] Electronic resourse: http://orwell.ru/library/ novels/1984/ (12.01.2018).

Shaw G. B., The Apple Cart, [in:] Electronic resourse: http://gutenberg.net.au/ ebooks03/0300431h.html (12.102017).

Szewozyk Łucja M., Funkcja wartościujaca nazewnictwa literackiego (na materiale wybranych dzieł Adama Mickiewicza), [w:] Onomastyka literacka, Olsztyn 1993. 